\title{
Methylene Blue Adsorption onto Cockle Shells-Treated Banana Pith: Optimization, Isotherm, Kinetic, and Thermodynamic Studies
}

\author{
Rosalyza Hasan ${ }^{1}$, Wong Jie Ying ${ }^{1}$, Chong Chi Cheng ${ }^{1}$, Nur Farhana Jaafar ${ }^{2}$, Rohayu Jusoh ${ }^{1}$, \\ Aishah Abdul Jalil ${ }^{3,4}$, and Herma Dina Setiabudi ${ }^{1,5,}$ \\ ${ }^{1}$ Faculty of Chemical and Natural Resources Engineering, Universiti Malaysia Pahang, \\ Lebuhraya Tun Razak 26300, Gambang, Pahang, Malaysia \\ ${ }^{2}$ School of Chemical Sciences, Universiti Sains Malaysia, 11800, Penang, Malaysia \\ ${ }^{3}$ School of Chemical and Energy Engineering, Faculty of Engineering, Universiti Teknologi Malaysia, \\ 81310 UTM Johor Bahru, Johor, Malaysia \\ ${ }^{4}$ Centre of Hydrogen Energy, Institute of Future Energy, Universiti Teknologi Malaysia, \\ 81310 UTM Johor Bahru, Johor, Malaysia \\ ${ }^{5}$ Centre of Excellence for Advanced Research in Fluid Flow (CARIFF), Universiti Malaysia Pahang, \\ Lebuhraya Tun Razak 26300, Gambang, Pahang, Malaysia
}

\section{* Corresponding author:}

tel: $+609-5492836$

email:herma@ump.edu.my

Received: August 3, 2018

Accepted: January 28, 2019

DOI: $10.22146 /$ ijc. 42822

\begin{abstract}
Two low-cost wastes, banana pith (BP) and cockle shells (CS) were explored towards methylene blue (MB) removal. The performance of cockle shells-treated banana pith (CS-BP) in $M B$ removal was compared with untreated BP and commercially $\mathrm{Ca}(\mathrm{OH})_{2}$-treated $\mathrm{BP}\left(\mathrm{Ca}(\mathrm{OH})_{2}-\mathrm{BP}\right)$. The adsorption efficacy was following the order of $B P<C S-B P<C a(O H)_{2}-B P$, indicating the positive role of alkaline treatment towards $M B$ removal and great potential of CS as a low-cost activation material. The optimization of $M B$ removal onto CS-BP was executed by response surface methodology (RSM) with three independent variables (adsorbent dosage $\left(X_{1}\right)$, initial $p H\left(X_{2}\right)$ and initial $M B$ concentration $\left(X_{3}\right)$ ), and the optimal condition was achieved at $X_{1}=1.17 \mathrm{~g} / \mathrm{L}, X_{2}=p H 7$ and $X_{3}=214 \mathrm{mg} / \mathrm{L}$, with $87.32 \%$ of predicted $M B$ removal. The experimental data wellfitted the pseudo-second-order kinetic $\left(R^{2}>0.99\right)$ and the Langmuir isotherm $\left(R^{2}=0.999\right)$ models, demonstrating the chemisorption and naturally homogeneous process. Thermodynamics study discovered that the MB removal by CS-BP is endothermic, feasible, spontaneous and randomness growth at a solid-solute interface. It is affirmed that CS could be employed as a low-cost activation material and CS-BP as a low-cost adsorbent.
\end{abstract}

Keywords: cockleshells; banana pith; methylene blue; low-cost adsorbent; alkaline treatment

\section{- INTRODUCTION}

Numerous industries are using dyes in coloring their final product and consequently caused severe problems in the form of colored wastewaters that require pretreatment before being disposed to the environment [1]. Majority of the commercial dyes used is poisonous to aquatic life owing to the existence of chlorides and metals. As a result, the treatment of dye-containing effluent is a crucial task and the scientific interest in decolorization of dye effluents has been increasing in the last few decades. The removal of dyes has been studied using several techniques including biological, physical and chemical methods, however, the biological method has not been very successful, owing to the essential nonbiodegradable nature of most of the dyes [2]. In addition, the high difficulty to treat dye-containing effluent can be 
claimed on the aerobic digestion resistant, recalcitrant organic molecules present and stability towards photo degradation, biodegradation and oxidizing agents [3].

Adsorption method appeared as the best technique among various dye removal techniques due to its good performance in the removal of different types of coloring materials [2,4-5]. Regarding the adsorbent material, activated carbon has been commercially used for adsorption process owing to its excellent adsorption ability [6-7]. Regrettably, its relatively high cost limits its widespread usage in wastewater treatment. For the sake of reducing the cost of treatment, alternative adsorbents, particularly from agricultural wastes, have been investigated and reported, on account of the arose disposal problem as well as the no economic value of agricultural wastes [2].

Banana pith (BP) is one of the agricultural wastes which is available abundantly all the year round, yet being disposed of without being utilized properly and effectively. Therefore, the attempt to utilize BP as an economical adsorbent not only can minimize environmental pollution but can also increase its economic value. However, the challenge arose when the untreated agricultural waste adsorbents possess drawbacks as reported in the literature, for instance, low performance in adsorption process [8].

Therein, researchers have studied the agricultural wastes activation, and alkaline treatment can be considered as one of the broadly adopted methods. It has been reported that alkaline treatment substantially influences the morphology of the adsorbent by producing a porous surface of adsorbent which is favorable for adsorption process [9]. However, in order to reduce the cost, it is desirable to study the utilization of wastes as alternative low-cost materials to substitute the commercial chemical materials for alkaline treatment. Cockle shells (CS) is an abundant and non-edible waste that is widely found in many coastal areas. Owing to the high composition of calcium carbonate $\left(\mathrm{CaCO}_{3}\right)$ in $\mathrm{CS}$, CS has great potential as an economical activation material for alkaline treatment of BP.

In this study, we attempt to use BP as a low-cost adsorbent and its adsorption competency was improved by employing the cockle shell (CS) as the low-cost activation material. Adsorption conditions of Methylene Blue (MB) removal onto cockle shells-treated banana pith (CS-BP) was optimized using Response Surface Methodology (RSM), while the physicochemical properties of fresh and spent adsorbent were analyzed using several characterization analyzers.

\section{- EXPERIMENTAL SECTION}

\section{Materials}

The banana piths (BPs) were collected from the banana farm, Pahang, Malaysia. The commercial calcium hydroxide $\left(\mathrm{Ca}(\mathrm{OH})_{2}\right)$ was purchased from Merck and used in the alkaline treatment of the adsorbent.

\section{Instrumentation}

Instruments used in this study included oven, furnace (Memmert UFB-500, Germany), stirring hotplate with digital display (Corning PC-420D), XRF (Bruker S8 TIGER ECO), FTIR (Nicolet iS5, Thermo Scientific), SEM (LYRA3 XM, Tescan) and BET (Quantachrome Autosorb-1 analyzer).

\section{Procedure}

\section{Preparation of adsorbent}

The BPs were cut into pieces in 1-2 cm length and soaked in water for adhering impurities elimination. The samples were oven-dried $\left(80^{\circ} \mathrm{C}, 12 \mathrm{~h}\right)$ before grounded and sieved (300-500 $\mu \mathrm{m})$. Meanwhile, the cockle shells (CS, collected from the beach, Pahang, Malaysia) were cleaned with water, dried $\left(80^{\circ} \mathrm{C}, 12 \mathrm{~h}\right)$, grounded to the specific size $(355-600 \mu \mathrm{m})$, and finally followed with calcination process $\left(850^{\circ} \mathrm{C}, 3 \mathrm{~h}\right)$. During the calcination process, calcium carbonate $\left(\mathrm{CaCO}_{3}\right)$ consist of $\mathrm{CS}$ changed to calcium oxide $(\mathrm{CaO})$ via the decomposition process $\left(\mathrm{CaCO}_{3} \rightarrow \mathrm{CaO}+\mathrm{CO}_{2}\right)$.

The BP pre-treatment with commercial $\mathrm{Ca}(\mathrm{OH})_{2}$ was performed in accordance with the method described in the literature [2]. In brief, $\mathrm{Ca}(\mathrm{OH})_{2}$ powder $(8.6 \mathrm{~g})$ was dissolved into deionized water $(1 \mathrm{~L})$, followed by the addition of powdered BP $(10 \mathrm{~g})$. The mixture was agitated (room temperature, $4 \mathrm{~h}$ ), filtered and oven-dried $\left(80^{\circ} \mathrm{C}\right.$, $12 \mathrm{~h}$ ) to produce $\mathrm{Ca}(\mathrm{OH})_{2}-\mathrm{BP}$. An identical technique was executed for preparing the CS-BP by using CS as 
alkaline material. The $\mathrm{CaO}$ consist of calcined CS converted into $\mathrm{Ca}(\mathrm{OH})_{2}$ once it contacts with $\mathrm{H}_{2} \mathrm{O}$.

\section{Characterization of adsorbent}

$\mathrm{XRF}$ was used to analyze the chemical composition of CS sample, meanwhile, the Fourier-transform infrared spectrometer (FTIR), surface area analyzer and scanning electron microscopy (SEM) were used to analyze the physicochemical properties of fresh adsorbents (BP, CS$\mathrm{BP}$ ) and spent adsorbent (MB-CS-BP). In brief, FTIR analysis was used for the study of adsorbents' chemical properties and functional groups involved in the adsorption process, while the morphological characteristics and surface features were studied using SEM. The textural properties (BET surface area $\left(\mathrm{S}_{\mathrm{BET}}\right)$ and pore volume $\left(\mathrm{V}_{\mathrm{p}}\right)$ ) of adsorbents were quantified using BET analyzer at $-196^{\circ} \mathrm{C}$.

\section{Adsorption experiments}

A total number of 16 adsorption experiments with 2 replicates at the center point were executed by alternating the process parameters corresponding to the experimental design generated by RSM for adsorption study. Prior to the adsorption experiments, the stock solution was prepared by dissolution of the finite quantity of measured MB $\left(\mathrm{C}_{16} \mathrm{H}_{18} \mathrm{~N}_{3} \mathrm{SCl}\right.$, C.I.52015, 99\%, Merck) in deionized water, before being adjusted to desired concentrations (50-500 mg/L) and $\mathrm{pH}(\mathrm{pH} 2-10)$. Adsorption experiments started with the addition of the requisite dosage of CS-BP (0.25-2.5 g/L) into MB solution $(200 \mathrm{~mL}$ ) under constant stirring (ambient temperature, $2 \mathrm{~h}$ ). The samples were taken out at proper time intervals, followed by centrifugation $(20 \mathrm{~min})$. UV/Vis spectrophotometer (LAMBDA 850, PerkinElmer) was used to identify the remaining $\mathrm{MB}$ concentration with maximum wavelength $\left(\lambda_{\max }\right)$ of $664 \mathrm{~nm}$. The experiments were conducted triplicates for accuracy. The amount of $\mathrm{MB}$ adsorbed at equilibrium, $\mathrm{q}_{\mathrm{t}}(\mathrm{mg} / \mathrm{g})$ and percentage of $\mathrm{MB}$ removal were calculated using Eq. (1) and (2), respectively.

$\mathrm{q}_{\mathrm{t}}=\left(\frac{\mathrm{C}_{0}-\mathrm{C}_{\mathrm{t}}}{\mathrm{W}}\right) \times \mathrm{V}$

Removal (\%) $=\left(\frac{\mathrm{C}_{0}-\mathrm{C}_{\mathrm{t}}}{\mathrm{C}_{0}}\right) \times 100$ where $\mathrm{C}_{0}$ and $\mathrm{C}_{\mathrm{t}}$ are the liquid phase concentration of the $\mathrm{MB}$ at time zero and at any time $\mathrm{t}(\mathrm{mg} / \mathrm{L}), \mathrm{W}$ is the adsorbent mass $(\mathrm{g})$ and $\mathrm{V}$ is the volume of the $\mathrm{MB}$ solution (L).

\section{Experiment design and optimization}

The process parameters influencing the adsorption process were analyzed using face-centered central design (FCCCD) method generated from RSM (Statsoft Statistica 8.0 software). Three independent variables (adsorbent dosage, initial $\mathrm{pH}$, and initial concentration) were selected, and their relationship with response (MB removal) was appraised by the equation model. The significant of the equation model was assessed using analysis of variance (ANOVA, 5\% level of significance) in accordance with the method described in the literature [10].

\section{Adsorption kinetics}

Pseudo-first-order and pseudo-second-order models were executed to govern the mechanism of the MB adsorption onto CS-BP. The linearized forms of the models are expressed as following equations [11]:

Pseudo-first-order:

$\log \left(\mathrm{q}_{\mathrm{e}}-\mathrm{q}_{\mathrm{t}}\right)=\log \mathrm{q}_{\mathrm{e}}-\frac{\mathrm{k}_{1}}{2.303} \mathrm{t}$

Pseudo-second-order:

$\frac{\mathrm{t}}{\mathrm{q}_{\mathrm{t}}}=\frac{1}{\mathrm{k}_{2} \mathrm{q}_{\mathrm{e}}^{2}}+\frac{1}{\mathrm{q}_{\mathrm{e}}} \mathrm{t}$

where $q_{e}$ and $q_{t}$ are the amounts of dye adsorbed at equilibrium $(\mathrm{mg} / \mathrm{g})$ and at any time $\mathrm{t}(\mathrm{mg} / \mathrm{g})$, and $\mathrm{k}_{1}$ and $\mathrm{k}_{2}$ are the adsorptions constant of pseudo-first-order and pseudo-second-order model.

\section{Adsorption isotherm}

Langmuir [12], Freundlich [13], Temkin [14], and Dubinin-Radushkevich [15] models were executed to analyze the type of $\mathrm{MB}$ distribution, as well as the interaction between CS-BP surface and MB molecules. The linearized forms of the models are expressed as following equations:

Langmuir:

$\frac{\mathrm{C}_{\mathrm{e}}}{\mathrm{q}_{\mathrm{e}}}=\frac{1}{\mathrm{q}_{\mathrm{m}} \mathrm{K}_{\mathrm{L}}}+\frac{\mathrm{C}_{\mathrm{e}}}{\mathrm{q}_{\mathrm{m}}}$ 
Freundlich:

$\log \mathrm{q}_{\mathrm{e}}=\log \mathrm{K}_{\mathrm{f}}+\frac{1}{\mathrm{n}} \log \mathrm{C}_{\mathrm{e}}$

Temkin:

$\mathrm{q}_{\mathrm{e}}=\mathrm{B} \ln \mathrm{A}+\mathrm{B} \ln \mathrm{C}_{\mathrm{e}}$

Dubinin-Radushkevich:

$\ln \mathrm{q}_{\mathrm{e}}=\ln \mathrm{q}_{\mathrm{m}}-\mathrm{K}_{\mathrm{DR}} \varepsilon^{2}$

where $\mathrm{C}_{\mathrm{e}}$ and $\mathrm{q}_{\mathrm{e}}$ are the $\mathrm{MB}$ concentration $(\mathrm{mg} / \mathrm{L})$ and $\mathrm{MB}$ adsorption capacity $(\mathrm{mg} / \mathrm{g})$ at equilibrium, while $\mathrm{q}_{\mathrm{m}}$ is the maximum adsorption capacity $(\mathrm{mg} / \mathrm{g}) . \mathrm{K}_{\mathrm{L}}$ and $\mathrm{K}_{\mathrm{f}}$ are the equilibrium constant for Langmuir $(\mathrm{L} / \mathrm{mg})$ and Freundlich $\left((\mathrm{mg} / \mathrm{g})(\mathrm{L} / \mathrm{mg})^{1 / \mathrm{n}}\right) . \mathrm{n}$ is an empirical constant for the Freundlich equation. For Eq. (8), A is the Temkin equilibrium binding constant $(\mathrm{L} / \mathrm{g})$, while $\mathrm{B}$ is the Temkin constant. For equation (9), $K_{D R}$ is the DubininRadushkevich constant $\left(\mathrm{mol}^{2} / \mathrm{kJ}^{2}\right)$ and $\varepsilon$ is the Polanyi potential $(\mathrm{J} / \mathrm{mol})$. $\varepsilon$ can be determined from $\varepsilon=\mathrm{RT} \ln$ $\left(1+1 / \mathrm{C}_{\mathrm{e}}\right)$, where $\mathrm{R}$ is the ideal gas constant $(8.314 \mathrm{~J} / \mathrm{mol} \cdot \mathrm{K})$ and $\mathrm{T}$ is absolute temperature $(\mathrm{K})$. The fundamental characteristic of the Langmuir isotherm can be analyzed using the dimensionless constant separation factor, $\mathrm{R}_{\mathrm{L}}\left(\mathrm{R}_{\mathrm{L}}\right.$ $\left.=1 /\left(1+\mathrm{K}_{\mathrm{L}} \mathrm{C}_{0}\right)\right)$ [16]. The value of $\mathrm{R}_{\mathrm{L}}$ parameter can be either $\mathrm{R}_{\mathrm{L}}=0,0<\mathrm{R}_{\mathrm{L}}<1, \mathrm{R}_{\mathrm{L}}=1$, or $\mathrm{R}_{\mathrm{L}}>1$, indicating to irreversible, favorable, linear, or unfavorable, respectively [16].

\section{Adsorption thermodynamic}

The Gibbs free energy $\left(\Delta \mathrm{G}^{\circ}\right)$, enthalpy $\left(\Delta \mathrm{H}^{\circ}\right)$ and entropy $\left(\Delta S^{\circ}\right)$ were evaluated to investigate the thermodynamic nature of $\mathrm{MB}$ adsorption over CS-BP and the equations used as follows [2]:

$\Delta \mathrm{G}^{\circ}=-\mathrm{RT} \ln \mathrm{K}_{\mathrm{D}}$

$\ln \mathrm{K}_{\mathrm{D}}=\frac{\Delta \mathrm{H}^{\circ}}{\mathrm{RT}}+\frac{\Delta \mathrm{S}^{\circ}}{\mathrm{R}}$

where $\mathrm{R}$ is the ideal gas constant $(8.314 \mathrm{~J} / \mathrm{mol} \cdot \mathrm{K}), \mathrm{T}$ is the absolute temperature $(\mathrm{K})$ and $\mathrm{K}_{\mathrm{D}}$ is the Langmuir isotherm constant (L/mg).

\section{- RESULTS AND DISCUSSION}

\section{Effect of Alkaline Treatment}

Fig. 1 depicts the influence of banana pith (BP) pretreatment on the methylene blue (MB) removal, in which the error bars representing the standard errors by the mean of three replicates of the experiments carried out in this study. The performance of untreated BP on the adsorption of $\mathrm{MB}$ was compared with treated $\mathrm{BP}$ $\left(\mathrm{Ca}(\mathrm{OH})_{2}-\mathrm{BP}\right.$ and $\left.\mathrm{CS}-\mathrm{BP}\right)$. The $\mathrm{Ca}(\mathrm{OH})_{2}-\mathrm{BP}(80.6 \%)$ and CS-BP (74.1\%) show higher adsorption uptake as compared to the untreated BP (66.5\%), indicating the positive role of alkaline treatment towards $\mathrm{MB}$ removal and great potential of CS as a low-cost activation material. The positive role of alkaline treatment might be due to an increase in the electronegativity and the surface areas of adsorbents after the alkaline treatment. The great potential of CS as an activation material in accordance with XRF analysis in which the calcined CS contains $98.2 \%$ of $\mathrm{CaO}$, which can be considered as a promising economical replacement over commercial $\mathrm{Ca}(\mathrm{OH})_{2}$. The positive role of adsorbent activation towards dye removal was also reported in the literature [17]. Jain and Gogate [9] found that the activation of Prunus dulcis leaves by $\mathrm{NaOH}$ increased the adsorption capacity of Prunus dulcis leaves towards Acid Blue 113 removal from 10.87 to $25.51 \mathrm{mg} / \mathrm{g}$ due to the presence of surface porous after $\mathrm{NaOH}$ activation which is favorable for adsorption process.

\section{Characterization of Untreated BP and Treated-BP}

The details on the functional groups involved during the pre-treatment process and the binding mechanism

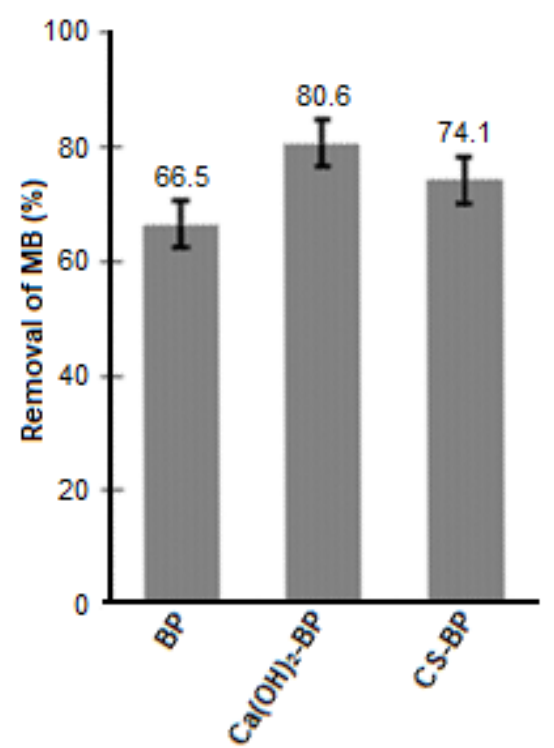

Fig 1. Influence of the alkaline treatment on the $\mathrm{MB}$ removal $\left(\mathrm{m}=0.5 \mathrm{~g} / \mathrm{L}, \mathrm{pH} 6, \mathrm{C}_{0}=100 \mathrm{mg} / \mathrm{L}, \mathrm{T}=30^{\circ} \mathrm{C}\right.$, contact time $=120 \mathrm{~min}$ ) 
between treated $\mathrm{BP}$ and $\mathrm{MB}$ molecules were determined using FTIR analysis as shown in Fig. 2. Several major absorbance bands at 3283, 2917, 1591, 1316, 1031, 460 and $438 \mathrm{~cm}^{-1}$ were observed for BP. In accordance with the literature, the broad absorption peak at $3283 \mathrm{~cm}^{-1}$ corresponded to the $\mathrm{O}-\mathrm{H}$ stretching in cellulose, while the peak observed at $2917 \mathrm{~cm}^{-1}$ assigned to the $\mathrm{C}-\mathrm{H}$ asymmetric stretching of $\mathrm{CH}_{2}$ groups $[10,18]$. The peaks at 1591 and $1316 \mathrm{~cm}^{-1}$ attributed to the $\mathrm{C}=\mathrm{C}$ and $\mathrm{C}=\mathrm{O}$ stretching, while 1031,460 and $438 \mathrm{~cm}^{-1}$ attributed to the C-H deformation. New bands were discerned at 1386, 871 and $711 \mathrm{~cm}^{-1}$ after the BP treatment with CS indicating the presence of inorganic carbonate, demonstrating the success of alkaline treatment process. After the MB adsorption onto CS-BP, the intensities of the bands were slightly decreased and the existence of organic sulfur was observed at the band of $1419 \mathrm{~cm}^{-1}$ [18]. The decreased in the intensity at 871 and $711 \mathrm{~cm}^{-1}$ bands and the presence of a new band at $1419 \mathrm{~cm}^{-1}$ provide strong evidence of the interactions between dye molecules with the inorganic carbonate of CS-BP in accordance with the literature [19].

The topology of BP, CS-BP, and MB-CS-BP was identify using SEM analysis and the result is shown in Fig. 3. Before the treatment with CS, the crushed particles with clustered arrangement can be seen on the surface of BP (Fig. 3(a)). Rough BP surface was observed after the CS pre-treatment (Fig. 3(b)) which signifies the high possibility of MB to be adsorbed. The smooth surface of CS-BP-MB (Fig. 3(c)) confirming the coverage of CS-BP surface with $\mathrm{MB}$ molecules via the adsorption process.

The textural properties $\left(\mathrm{S}_{\mathrm{BET}}\right.$ and $\mathrm{V}_{\mathrm{p}}$ ) of BP, CS-BP and $\mathrm{MB}-\mathrm{CS}-\mathrm{BP}$ were $\mathrm{S}_{\mathrm{BET}}=12.31,16.06$ and $11.51 \mathrm{~m}^{2} / \mathrm{g}$, respectively, and $\mathrm{V}_{\mathrm{p}}=0.019,0.023$ and $0.011 \mathrm{~cm}^{3} / \mathrm{g}$, respectively. The findings revealed that the activation of BP using CS increase the number of pores and thus increase the $S_{\text {BET }}$ and $V_{p}$. This advantage increases the possibility of $\mathrm{MB}$ molecules to be trapped onto the surface and pores of CS-BP, which was evidenced by the decrease of $S_{B E T}$ and $V_{p}$ for MB-CS-BP. The changes in the surface features of adsorbent by alkaline activation were also reported by Jain and Gogate (2017) for $\mathrm{NaOH}$ treated Prunus dulcis leaves [9]. They stated that the increment in $S_{\text {BET }}$ and $V_{p}$ of the adsorbent which is favorable for adsorption process indeed resulted from the pores evolved upon $\mathrm{NaOH}$ activation.

\section{Statistical Analysis of MB Removal by CS-BP}

The influences of the independent variables on the response had been investigated by the batch study of 16 experiments using RSM and the results were presented in Table 1.

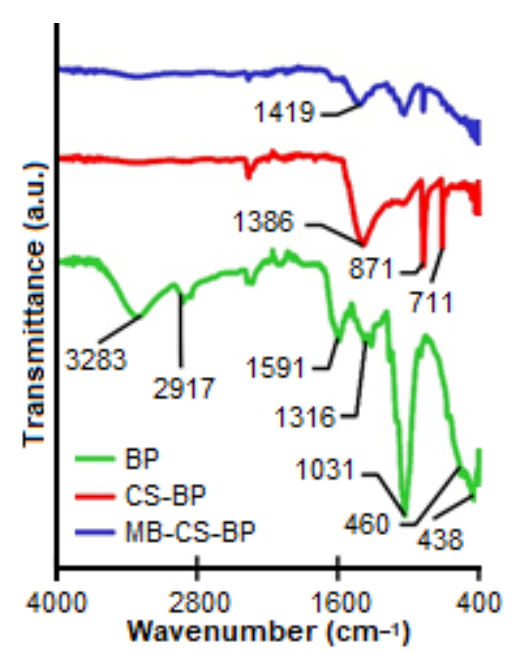

Fig 2. FTIR spectra of BP, CS-BP, and MB-CS-BP
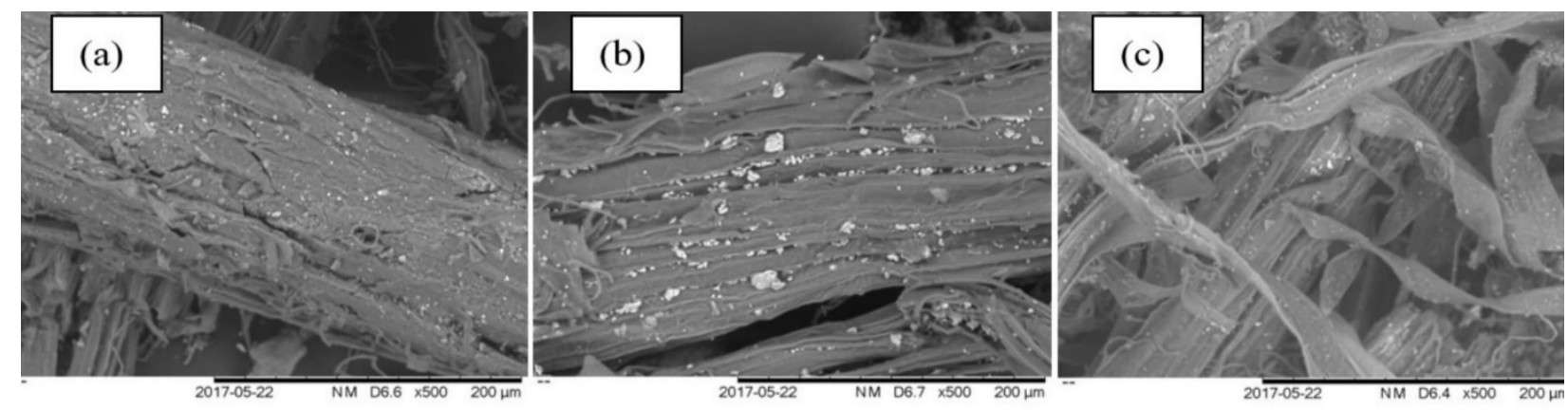

Fig 3. SEM images of (a) BP, (b) CS-BP, (c) MB-CS-BP 
The quadratic model for MB removal by CS-BP is presented in Eq. (11):

$$
\begin{aligned}
\mathrm{Y} & =65.9826+6.6710 \mathrm{X}_{1}+4.3866 \mathrm{X}_{2}+0.0253 \mathrm{X}_{3}-1.5075 \mathrm{X}_{1}^{2} \\
& -0.2736 \mathrm{X}_{2}^{2}-0.00004 \mathrm{X}_{3}^{2}-0.4139 \mathrm{X}_{1} \mathrm{X}_{2}-0.0017 \mathrm{X}_{1} \mathrm{X}_{3} \\
& -0.0011 \mathrm{X}_{2} \mathrm{X}_{3}
\end{aligned}
$$

The validity of the statistical model was analyzed by plotting the graph of predicted values versus the experimental values (not shown). The linear coefficient of the graph is 0.9786 implying the reasonable of predicted values in conformity with the experimental values. The statistical significance of the model was accessed using ANOVA and the result was tabulated in Table 2. The result discovered the significance of the model as expressed by the larger F-value (30.671) in comparison with the tabulated F-value (4.10).

Fig. 4 shows the Pareto chart of MB removal onto CS-BP. The critical parameter for the regression model represents the smaller magnitude of the p-value and larger magnitude of the t-value. As shown in Fig. 4, all linear, quadratic and interaction terms are statistically significant $(\mathrm{p}<0.05)$ excluding linear term of adsorbent

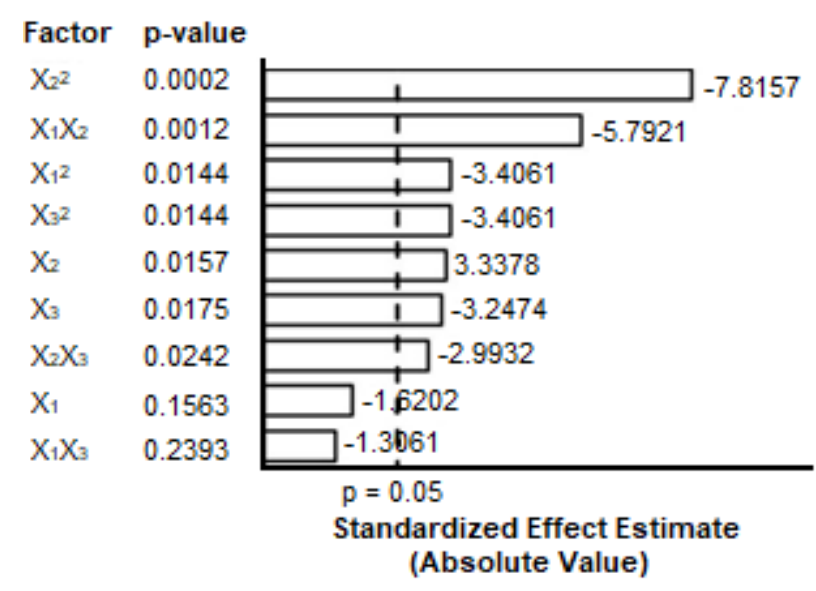

\begin{tabular}{|c|c|c|c|c|c|c|c|}
\hline \multirow{3}{*}{ Run } & \multicolumn{6}{|c|}{ Independent variables } & \multirow{3}{*}{$\begin{array}{l}\text { Response } \\
\text { MB removal, } \\
Y(\%)\end{array}$} \\
\hline & \multicolumn{2}{|c|}{ Adsorbent dosage, $\mathrm{X}_{1}(\mathrm{~g} / \mathrm{L})$} & \multicolumn{2}{|c|}{ Initial $\mathrm{pH}, \mathrm{X}_{2}$} & \multicolumn{2}{|c|}{ Initial Concentration, $\mathrm{X}_{3}(\mathrm{mg} / \mathrm{L})$} & \\
\hline & Coded & Uncoded & Coded & Uncoded & Coded & Uncoded & \\
\hline 1 & -1 & 0.25 & -1 & 2 & -1 & 50 & 75.89 \\
\hline 2 & -1 & 0.25 & -1 & 2 & 1 & 500 & 76.50 \\
\hline 3 & -1 & 0.25 & 1 & 10 & -1 & 50 & 83.10 \\
\hline 4 & -1 & 0.25 & 1 & 10 & 1 & 500 & 81.00 \\
\hline 5 & 1 & 2.50 & -1 & 2 & -1 & 50 & 79.47 \\
\hline 6 & 1 & 2.50 & -1 & 2 & 1 & 500 & 79.54 \\
\hline 7 & 1 & 2.50 & 1 & 10 & -1 & 50 & 80.37 \\
\hline 8 & 1 & 2.50 & 1 & 10 & 1 & 500 & 75.45 \\
\hline 9 & -1 & 0.25 & 0 & 6 & 0 & 275 & 86.50 \\
\hline 10 & 1 & 2.50 & 0 & 6 & 0 & 275 & 83.50 \\
\hline 11 & 0 & 1.375 & -1 & 2 & 0 & 275 & 81.99 \\
\hline 12 & 0 & 1.375 & 1 & 10 & 0 & 275 & 83.07 \\
\hline 13 & 0 & 1.375 & 0 & 6 & -1 & 50 & 86.50 \\
\hline 14 & 0 & 1.375 & 0 & 6 & 1 & 500 & 83.50 \\
\hline $15(\mathrm{C})$ & 0 & 1.375 & 0 & 6 & 0 & 275 & 87.28 \\
\hline $16(\mathrm{C})$ & 0 & 1.375 & 0 & 6 & 0 & 275 & 87.50 \\
\hline
\end{tabular}

Fig 4. Pareto chart of MB removal by CS-BP

Table 1. The design of experiments and experimental response for MB removal by CS-BP

Table 2. ANOVA results for MB removal by CS-BP

\begin{tabular}{lcccc}
\hline Sources & Sum of Square (SS) & Degree of Freedom (df) & Mean Square (MS) & F-value \\
\hline Regression (SSR) & 227.10 & 9 & 25.233 & 30.671 \\
Residual & 4.9362 & 6 & 0.8227 & \\
Total (SST) & 232.03 & 15 & & \\
\hline
\end{tabular}


dosage $\left(\mathrm{X}_{1}\right)$ and an interaction term of adsorbent dosage and initial concentration $\left(\mathrm{X}_{1} \mathrm{X}_{3}\right)$. The quadratic term of initial $\mathrm{pH}\left(\mathrm{X}_{2}{ }^{2}\right)$ was the utmost crucial variables for the adsorption of MB onto CS-BP.

Meanwhile, the least crucial factor on the MB adsorption was indicated by the $\mathrm{X}_{1} \mathrm{X}_{3}$. The crucial of the initial $\mathrm{pH}$ probably due to the properties of $\mathrm{MB}$, which exists in the form of positively charged ions in aqueous solution. Thus, the changes in the charge of the initial MB solution will influence the adsorption performance.

Fig. 5 displays the 3D plots showing the influences of independent variables towards the removal of MB. As displayed in Fig. 5(a), the percentage of MB removal inclined parallel with the increment in adsorbent dosage and initial pH. At the adsorbent dosage of $0.8-1.5 \mathrm{~g} / \mathrm{L}$ and an initial $\mathrm{pH}$ of 5.5-7.5, the maximum dye removal of $>86 \%$ was accomplished before slightly decreased at higher values. As the adsorbent dosage was increased, the quantity of the binding sites accessible for adsorption was increased as well due to the rise in the adsorbent's dosage.

Meanwhile, the enhancement of the MB removal at higher $\mathrm{pH}$ can be claimed on the electrostatically adsorbed of the positively charged of $\mathrm{MB}$ cations onto the negatively charged surface of CS-BP [20]. The influence of $\mathrm{pH}$ on the adsorption performance can be depicted on the basis of zero-point change $\left(\mathrm{pH}_{\mathrm{zpc}}\right)$ of the CS-BP, which was confirmed at $\sim \mathrm{pH} 7.45$. The influence of $\mathrm{pH}$ on the removal percentage in agreement with the report declared for the MB removal onto cashew nutshell [21] and breadnut peel [22], in which the MB withdrawal percentage increased with increment in initial $\mathrm{pH}$.

Fig. 5(b) displays the 3D plot for the influences of adsorbent dosage $\left(X_{1}\right)$ and the initial concentration $\left(\mathrm{X}_{3}\right)$ on the MB removal percentage. The percentage of $M B$ removal increase with the increase of the adsorbent dosage. In contrast, the $\mathrm{MB}$ removal was declined with the increment of the MB initial concentration. The reduced in the percentage of $\mathrm{MB}$ removal at higher concentration probably be due to the inadequate quantity of active adsorbent sites to accommodate the high concentration of dye ions [23]. The highest dye removal (> 86\%) was accomplished at 0.9-1.6 g/L adsorbent dosage and 150-300 mg/L initial concentration.

The influences of initial $\mathrm{pH}\left(\mathrm{X}_{2}\right)$ and initial concentration $\left(X_{3}\right)$ on the $\mathrm{MB}$ removal are illustrated in Fig. 5(c). The plot shows that increasing $\mathrm{pH}$ and reducing initial MB concentration will subsequently increase the percentage of MB removal. This result related to the changes in the charge of the adsorbent surface and the ratio of dyes to the available surface site [24]. It was discovered that $>86 \%$ of $\mathrm{MB}$ withdrawal was acquired in the range of 5.5-7.5 initial $\mathrm{pH}$ and $150-300 \mathrm{mg} / \mathrm{L}$ initial concentration. An identical trend was claimed for the MB adsorption onto chitosan/zeolite composite [25], in which the $\mathrm{MB}$ withdrawal percentage increased with the growth of initial $\mathrm{pH}$ but a decline in the initial dye concentration.

The optimization study revealed that the optimal $\mathrm{MB}$ removal onto CS-BP was at $1.17 \mathrm{~g} / \mathrm{L}$ adsorbent dosage, initial $\mathrm{pH}$ of 7 and $214 \mathrm{mg} / \mathrm{L}$ initial concentration with predicted percentage MB removal of $87.32 \%$. An additional experiment was carried out at the optimal condition as validation purpose and the result showed $80.07 \%$ of MB removal was achieved. (a)

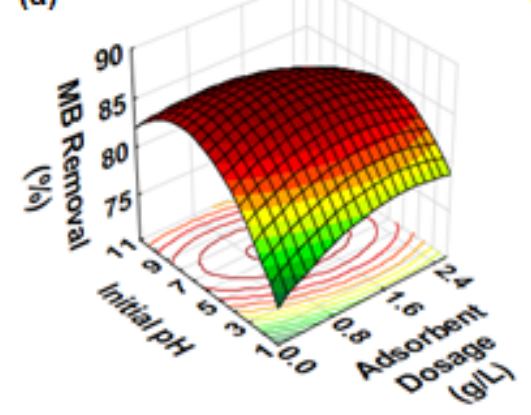

(b)

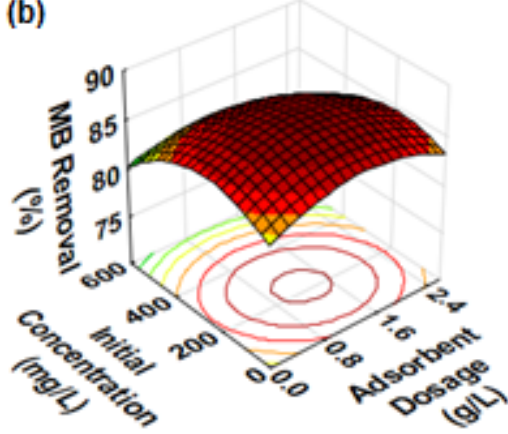

(c)

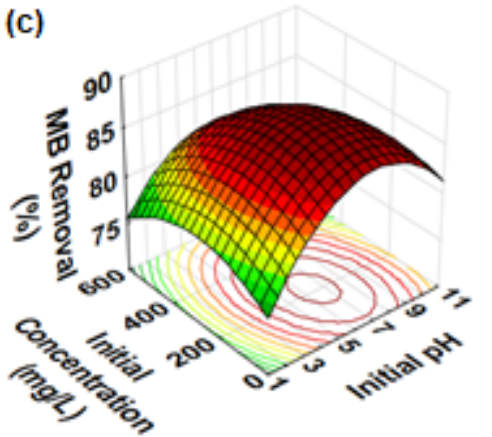

Fig 5. Response surface plots showing influences of (a) adsorbent dosage - initial pH interaction, (b) adsorbent dosage - initial concentration interaction, and (c) initial $\mathrm{pH}$ - initial concentration interaction, towards $\mathrm{MB}$ removal by CS-BP 
Table 3. Kinetic parameters for adsorption of MB by CS-BP

\begin{tabular}{llccccc}
\hline Kinetic Model & Parameters & $50 \mathrm{mg} / \mathrm{L}$ & $100 \mathrm{mg} / \mathrm{L}$ & $200 \mathrm{mg} / \mathrm{L}$ & $300 \mathrm{mg} / \mathrm{L}$ & $500 \mathrm{mg} / \mathrm{L}$ \\
\hline Experimental & $\mathrm{q}_{\text {e,exp }}(\mathrm{mg} / \mathrm{g})$ & 42.18 & 57.54 & 76.16 & 80.65 & 83.76 \\
Pseudo-first order & $\mathrm{q}_{\mathrm{e}}(\mathrm{mg} / \mathrm{g})$ & 2.575 & 4.462 & 4.467 & 4.558 & 4.788 \\
& $\mathrm{k}_{1}\left(\mathrm{~min}^{-1}\right)$ & 0.136 & 0.026 & 0.022 & 0.020 & 0.022 \\
& $\mathrm{R}^{2}$ & 0.962 & 0.966 & 0.971 & 0.981 & 0.932 \\
Pseudo-second order & $\mathrm{q}_{\mathrm{e}}(\mathrm{mg} / \mathrm{g})$ & 42.017 & 59.172 & 76.923 & 81.301 & 84.033 \\
& $\mathrm{k}_{2}\left(\mathrm{~min}^{-1}\right)$ & 0.008 & 0.003 & 0.003 & 0.002 & 0.002 \\
& $\mathrm{R}^{2}$ & 0.997 & 0.993 & 0.995 & 0.994 & 0.992 \\
\hline
\end{tabular}

\section{Adsorption Kinetic}

The kinetic study was carried out at $\mathrm{m}_{\mathrm{CS}-\mathrm{BP}}=1.17 \mathrm{~g} / \mathrm{L}$, $\mathrm{pH} 7, \mathrm{~T}=30^{\circ} \mathrm{C}$ and $\mathrm{C}_{0}=50-500 \mathrm{mg} / \mathrm{L}$. As tabulated in Table 3, pseudo-second-order model was shown as the best model with higher $\mathrm{R}^{2}(>0.992)$ and closer $\mathrm{q}_{\mathrm{e}}$ values to experimental data $\left(\mathrm{q}_{\mathrm{e}, \text { exp }}\right)$ in comparison with the pseudofirst-order model. The findings depicted that the MB adsorption by CS-BP was controlled by the chemisorption process and the number of the available active sites directly affect the rate of reaction. The comparable adsorption kinetic finding was reported for $\mathrm{MB}$ adsorption by oil palm ash zeolite/chitosan [26], weeds [27] and Ficus carica bast [18].

\section{Adsorption Isotherm}

The isotherm study was executed at $\mathrm{m}_{\mathrm{CS}-\mathrm{BP}}=1.17 \mathrm{~g} / \mathrm{L}$, $\mathrm{pH} 7, \mathrm{~T}=30^{\circ} \mathrm{C}$ and $\mathrm{C}_{0}=50-500 \mathrm{mg} / \mathrm{L}$. As tabulated in Table 4, the Langmuir isotherm model was shown as the best model with the highest $\mathrm{R}^{2}(0.999)$ amongst the four isotherms employed. The good fitting with the Langmuir isotherm model depicted that the MB adsorption onto CS-BP is monolayer adsorption and takes place on a surface that is homogeneous in nature [28]. Corresponding to Table 4 , the $\mathrm{K}_{\mathrm{L}}$ value was 0.102 which expresses that the $\mathrm{MB}$ molecules are favorably adsorbed on CS-BP with maximum adsorption capacity, $\mathrm{q}_{\mathrm{m}}$ of $85.47 \mathrm{mg} / \mathrm{g}$. An indistinguishable tendency was proclaimed for $\mathrm{MB}$ adsorption onto biomass fly ash geopolymer monoliths [29]. The value of $\mathrm{q}_{\mathrm{m}}$ was compared to several untreated and modified biosorbents were tabulated in Table 5. As observed, CS-BP has superior adsorption volume than the others, denoting the

Table 4. Isotherm parameters for MB removal onto CSBP

\begin{tabular}{lll}
\hline Isotherm Model & Parameters & Value \\
\hline Langmuir & $\mathrm{R}^{2}$ & 0.999 \\
& $\mathrm{q}_{\mathrm{m}}(\mathrm{mg} / \mathrm{g})$ & 85.47 \\
& $\mathrm{~K}_{\mathrm{L}}(\mathrm{L} / \mathrm{mg})$ & 0.102 \\
\multirow{4}{*}{ Freundlich } & $\mathrm{R}_{\mathrm{L}}$ & 0.089 \\
& $\mathrm{R}^{2}$ & 0.959 \\
& $\mathrm{n}$ & 8.953 \\
Temkin & $\mathrm{K}_{\mathrm{f}}(\mathrm{mg} / \mathrm{g})(\mathrm{L} / \mathrm{mg})^{1 / \mathrm{n}}$ & 5.124 \\
& $\mathrm{R}^{2}$ & 0.930 \\
& $\mathrm{~B}(\mathrm{~J} / \mathrm{mol})$ & 15.44 \\
Dubinin- & $\mathrm{A}(\mathrm{L} / \mathrm{g})$ & 15.65 \\
Radushkevich & $\mathrm{R}^{2}$ & 0.974 \\
& $\mathrm{q}_{\mathrm{m}}(\mathrm{mg} / \mathrm{g})$ & 6.756 \\
\hline
\end{tabular}

Table 5. Comparison of maximum adsorption capacity of MB onto various untreated and modified low-cost adsorbents

\begin{tabular}{lcl}
\hline Adsorbent & Adsorption capacity $(\mathrm{mg} / \mathrm{g})$ & Ref \\
\hline Cockle shells-treated banana pith & 85.47 & This study \\
Banana empty fruit bunch AC- $\mathrm{H}_{3} \mathrm{PO}_{4}$ & 76.13 & {$[30]$} \\
Banana empty fruit bunch AC- $\mathrm{KOH}$ & 71.06 & {$[30]$} \\
Salix babylonica (Weeping willow) leaves & 60.97 & {$[31]$} \\
Banana leaves AC & 48.01 & {$[32]$} \\
Haloxylon recurvum stems & 22.93 & {$[33]$} \\
Brazil nut shells & 7.81 & {$[34]$} \\
\hline
\end{tabular}


Table 6. Thermodynamic parameter for MB removal onto CSBP

\begin{tabular}{llccc}
\hline$\Delta \mathrm{H}^{\circ}$ & $\Delta \mathrm{S}^{\circ}$ & \multicolumn{3}{c}{$\Delta \mathrm{G}^{\circ}(\mathrm{kJ} / \mathrm{mol})$} \\
\cline { 3 - 5 }$(\mathrm{kJ} / \mathrm{mol})$ & $(\mathrm{J} / \mathrm{mol} \cdot \mathrm{K})$ & $30^{\circ} \mathrm{C}$ & $35^{\circ} \mathrm{C}$ & $40^{\circ} \mathrm{C}$ \\
\hline 13.7455 & 57.0041 & -3.5281 & -3.8087 & -4.0983 \\
\hline
\end{tabular}

capability of CS-BP as an alternate low-cost adsorbent for $\mathrm{MB}$ removal.

\section{Thermodynamic Study}

The thermodynamic study was investigated at optimal condition $\left(\mathrm{m}_{\mathrm{CS}-\mathrm{BP}}=1.17 \mathrm{~g} / \mathrm{L}, \mathrm{pH} 7, \mathrm{C}_{0}=214 \mathrm{mg} / \mathrm{L}\right.$, and time of contact $=120 \mathrm{~min}$ ) within $30-40{ }^{\circ} \mathrm{C}$ temperature range and the findings are listed in Table 6. The positive values of $\Delta \mathrm{H}^{\circ}(+13.7455 \mathrm{~kJ} / \mathrm{mol})$ and $\Delta \mathrm{S}^{\circ}(+$ $57.0041 \mathrm{~J} / \mathrm{mol}$ ) indicated the endothermic process and randomness increment at a solid-solute interface with certain structural alternations in adsorbent and adsorbate [35]. The decreasing $\Delta \mathrm{G}^{\circ}$ values with increasing temperature indicates that the removal of $\mathrm{MB}$ onto CS-BP is feasible, spontaneous and increase in the degree of spontaneity at a higher temperature.

\section{- CONCLUSION}

A new low-cost adsorbent (cockle shells-treated banana pith (CS-BP)) was successfully developed owing to its effectiveness in $\mathrm{MB}$ removal. Besides providing additional advantageous over industrial wastewater treatment, the solid wastes disposal of CS and BP can also be minimized. Investigation of MB removal by RSM under three independent parameters (adsorbent dosage $\left(\mathrm{X}_{1}\right)$, initial $\mathrm{pH}\left(\mathrm{X}_{2}\right)$ and initial dye concentration $\left(\mathrm{X}_{3}\right)$ ) was executed. Optimum condition $\left(\mathrm{X}_{1}=1.17 \mathrm{~g} / \mathrm{L}, \mathrm{X}_{2}=\mathrm{pH}\right.$ $7, \mathrm{X}_{3}=214 \mathrm{mg} / \mathrm{L}$ ) yielded predicted $\mathrm{MB}$ removal of 87.32\% (according to RSM). Based on the Pareto chart, the most paramount factor for MB removal by CS-BP was the $\mathrm{X}_{2}^{2}$. The experimental data was well-fitted with pseudo-second-order kinetic and Langmuir isotherm models, demonstrated a chemisorption process with monolayer and homogeneous process. Thermodynamic investigations revealed that the $\mathrm{MB}$ adsorption onto CS$\mathrm{BP}$ is an endothermic, randomness growth at the solidsolute interface, feasible, spontaneous and increase in the degree of spontaneity at a higher temperature.
The higher surface area, the presence of new bands which implies the existence of inorganic carbonate and rough surface of CS-BP as shown by BET, FTIR and SEM results, demonstrating the success of the alkaline treatment process. These combinations are the main contributors to the good MB adsorption by CS-BP.

\section{- ACKNOWLEDGMENTS}

This study was financially supported by Universiti Malaysia Pahang, Malaysia via Research University Grant (RDU170331).

\section{- REFERENCES}

[1] Hasan, R., Razifuddin, N.A.M., Jusoh, N.W.C., Jusoh, R., and Setiabudi, H.D., 2018, Artocarpus integer peel as a highly effective low-cost adsorbent for methylene blue removal: Kinetics, isotherm, thermodynamic and pelletized studies, Malays. J. Fundam. Appl. Sci., 14 (1), 25-31.

[2] Hasan, R., Chong, C.C., Setiabudi, H.D., Jusoh, R., and Jalil, A.A., 2019, Process optimization of methylene blue adsorption onto eggshell-treated palm oil fuel ash, Environ. Technol. Innovation, 13, 62-73.

[3] Liu, Q., Yang, B., Zhang, L., and Huang, R., 2015, Adsorption of an anionic azo dye by cross-linked chitosan/bentonite composite, Int. J. Biol. Macromol., 72, 1129-1135.

[4] Vezentsev, A., Thuy, D.M., Goldovskaya-Peristaya, L.F., and Glukhareva, N.A., 2018, Adsorption of methylene blue on the composite sorbent based on bentonite-like clay and hydroxyapatite, Indones. $J$. Chem., 18 (4), 733-741.

[5] Abdullah, R.H., Oda, A.M., Omran, A.R., Mottaleb, A.S., and Mubarakah, T.M., 2018, Study of adsorption characteristics a low-cost sawdust for the removal of direct blue 85 dye from aqueous solutions, Indones. J. Chem., 18 (4), 724-732.

[6] Osasona, I., Aiyedatiwa, K., Johnson, J.A., and Faboya, O.L., 2018, Activated carbon from spent brewery barley husks for cadmium ion adsorption from aqueous solution, Indones. J. Chem., 18 (1), 145-152. 
[7] Taba, P., 2009, Nitrogen, water and benzene adsorption in mesoporous carbon (CMK-1) and commercial activated carbon (NORIT SX22), Indones. J. Chem., 9 (3) 386-390.

[8] Fadzil, F., Ibrahim, S., and Hanafiah, M.A.K.M., 2016, Adsorption of lead(II) onto organic acid modified rubber leaf powder: Batch and column studies, Process Saf. Environ. Prot., 100, 1-8.

[9] Jain, S.N., and Gogate, P.R., 2017, Acid blue 113 removal from aqueous solution using novel biosorbent based on $\mathrm{NaOH}$ treated and surfactantmodified fallen leaves of Prunus dulcis, J. Environ. Chem. Eng., 5 (4), 3384-3394.

[10] Setiabudi, H.D., Jusoh, R., Suhaimi, S.F.R.M., and Masrur, S.F., 2016, Adsorption of methylene blue onto oil palm (Elaeis guineensis) leaves: Process optimization, isotherm, kinetics, and thermodynamic studies, J. Taiwan Inst. Chem. Eng., 63, 363-370.

[11] Chen, L., Li, Y., Du, Q., Wang, Z., Xia, Y., Yedinak, E., Lou, J., and Ci, L., 2017, High-performance agar/graphene oxide composite aerogel for methylene blue removal, Carbohydr. Polym., 155, 345-353.

[12] Langmuir, I., 1918, The adsorption of gases on plane surfaces of glass, mica and platinum, J. Am. Chem. Soc., 40 (9), 1361-1403.

[13] Freundlich, H., 1906, Over adsorption in solution, J. Phys. Chem. A, 57, 385-470.

[14] Tempkin, M.I., and Pyzhev, V., 1940, Kinetics of ammonia synthesis on promoted iron catalyst, Acta Physicochim. U.R.S.S., 12, 327-356.

[15] Dubinin, M.M., 1906, The potential theory of adsorption of gases and vapors for adsorbents with an energetically non-uniform surface, Chem. Rev., 60 (2), 235-241.

[16] Hasan, R., Bukhari, S.N., Jusoh, R., Mutamin, N.S.A., and Setiabudi, H.D., 2018, Adsorption of $\mathrm{Pb}$ (II) onto KCC-1 from aqueous solution: Isotherm and kinetic study, Mater. Today: Proc., 5 (10), 21574-21583.

[17] Spagnoli, A.A., Giannakoudakis, D.A., and Bashkova, S., 2017, Adsorption of methylene blue on cashew nut shell based carbons activated with zinc chloride: The role of surface and structural parameters, J. Mol. Liq., 229, 465-471.
[18] Pathania, D., Sharma, S., and Singh, P., 2017, Removal of methylene blue by adsorption onto activated carbon developed from Ficus carica bast, Arabian J. Chem., 10 (Suppl. 1), S1445-S1451.

[19] Liang, S., Guo, X., Feng, N., and Tian, Q., 2010, Isotherms, kinetics and thermodynamic studies of adsorption of $\mathrm{Cu}^{2+}$ from aqueous solutions by $\mathrm{Mg}^{2+} / \mathrm{K}^{+}$type orange peel adsorbents, J. Hazard. Mater., 174 (1-3), 756-762.

[20] Hameed, B.H., Mahmoud, D.K., and Ahmad, A.L., 2008, Equilibrium modeling and kinetic studies on the adsorption of basic dye by a low-cost adsorbent: Coconut (Cocos nucifera) bunch waste, J. Hazard. Mater., 158 (1), 65-72.

[21] Subramaniam, R., and Ponnusamy, S.K., 2015, Novel adsorbent from agricultural waste (cashew nut shell) for methylene blue dye removal: Optimization by response surface methodology, Water Resour. Ind., 11, 64-70.

[22] Lim, L.B.L., Priyantha, N., Tennakoon, D.T.B., Chieng, H.I., Dahri, M.K., and Suklueng, M., 2017, Breadnut peel as a highly effective low-cost biosorbent for methylene blue: Equilibrium, thermodynamic and kinetic studies, Arabian J. Chem., 10 (Suppl. 2), S3216-S3228.

[23] Islam, M.A., Ahmed, M.J., Khanday, W.A., Asif, M., and Hameed, B.H., 2017, Mesoporous activated carbon prepared from $\mathrm{NaOH}$ activation of rattan (Lacosperma secundiflorum) hydrochar for methylene blue removal, Ecotoxicol. Environ. Saf., 138, 279-285.

[24] Saeed, M., Nadeem, R., and Yousaf, M., 2015, Removal of industrial pollutant (reactive orange 122 dye) using environment-friendly sorbent Trapa bispinosa's peel and fruit, Int. J. Environ. Sci. Technol., 12 (4), 1223-1234.

[25] Dehghani, M.H., Dehghan, A., Alidadi, H., Dolatabadi, M., Mehrabpour, M., and Converti, A., 2017, Removal of methylene blue dye from aqueous solutions by a new chitosan/zeolite composite from shrimp waste: Kinetic and equilibrium study, Korean J. Chem. Eng., 34 (6), 1699-1707. 
[26] Khanday, W.A., Asif, M., and Hameed, B.H., 2017, Cross-linked beads of activated oil palm ash zeolite/chitosan composite as a bio-adsorbent for the removal of methylene blue and acid blue 29 dyes, Int . J. Biol. Macromol., 95, 895-902.

[27] Güzel, F., Sayğıll, H., Sayğıllı, G.A., Koyuncu, F., and Y1lmaz, C., 2017, Optimal oxidation with nitric acid of biochar derived from pyrolysis of weeds and its application in removal of hazardous dye methylene blue from aqueous solution, J. Cleaner Prod., 144, 260-265.

[28] Karim, A.H., Jalil, A.A., Triwahyono, S., Kamarudin, N.H.N., and Ripin, A., 2014, Influence of multiwalled carbon nanotubes on textural and adsorption characteristics of in situ synthesized mesostructured silica, J. Colloid Interface Sci., 421, 93-102.

[29] Novais, R.M., Ascensão, G., Tobaldi, D.M., Seabra, M.P., and Labrincha, J.A., 2018, Biomass fly ash geopolymer monoliths for effective methylene blue removal from wastewaters, J. Cleaner Prod., 171, 783-794.

[30] Sugumaran, P., Susan, V.P., Ravichandran, P., and Seshadri, S., 2012, Production and characterization of activated carbon from banana empty fruit bunch and Delonix regia fruit pod, J. Sustainable Energy Environ., 3, 125-132.

[31] Khodabandehloo, A., Rahbar-Kelishami, A., and
Shayesteh, H, 2017, Methylene blue removal using Salix babylonica (weeping willow) leaves powder as a low-cost biosorbent in batch mode: Kinetic, equilibrium, and thermodynamic studies, J. Mol. Liq., 244, 540-548.

[32] Martín-González, M.A., Susial, P., Pérez-Peña, J., and Doña-Rodríguez, J.M., 2013, Preparation of activated carbons from banana leaves by chemical activation with phosphoric acid: Adsorption of methylene blue, Rev. Mex. Ing. Quim., 12 (3), 595608.

[33] Hassan, W., Farooq, U., Ahmad, M., Athar, M., and Khan, M.A., 2017, Potential biosorbent, Haloxylon recurvum plant stems, for the removal of methylene blue dye, Arabian J. Chem., 10 (Suppl. 2), S1512S1522.

[34] de Oliveira Brito, S.M., Andrade, H.M.C., Soares, L.F., and de Azevedo, R.P., 2010, Brazil nut shells as a new biosorbent to remove methylene blue and indigo carmine from aqueous solutions, J. Hazard. Mater., 174 (1-3), 84-92.

[35] Salleh, N.F.M., Jalil, A.A., Triwahyono, S., Ripin, A., Sidik, S.M., Fatah, N.A.A., Salamun, N., Jaafar, N.F., and Hassim, M.H., 2017, New direct consecutive formation of spinel phase in $(\mathrm{Fe}, \mathrm{Co}, \mathrm{Ni}) \mathrm{Al}_{2} \mathrm{O}_{4}$ composites for enhanced $\mathrm{Pd}(\mathrm{II})$ ions removal, $J$. Alloys Compd., 727, 744-756. 